\title{
Asijské umění a umělecké řemeslo ve sbírce Západočeského muzea v Plzni
}

\section{Asian Art and Craft in the Collection of the West Bohemian Museum in Pilsen}

Abstract: The collection of the West Bohemian Museum in Pilsen includes significant examples of artworks and decorative arts from Asia. The history of this collection dates back to the last quarter of the 19th century, when these items were a part of a collection of the West Bohemian Museum of Decorative Arts in Pilsen. The first director of the museum, architect Josef Škorpil (1856-1931), contributed to the creation of the decorative arts collection and the acquisition of objects from the Far and Middle East. Thanks to its acquisition activities throughout Europe, a significant decorative arts collection was established in Pilsen. Its importance goes beyond the Pilsen region. The concept of creating this collection was in accordance with the emergence of decorative arts museums in Europe. The collection, together with the Asian objects, was presented to the public as a part of an exposition opened in 1913. Today, the Asian collection consists of Chinese and Korean objects, mainly ceramics and porcelain, as well as exceptionally well-preserved textiles from the late Qing Dynasty. The Japanese portable Buddhist altar zushi or a set of Japanese woodblock prints of the ukiyo-e style are among the most unique acquisitions. A relatively modest set of items from the Middle East includes typical examples of decorative arts from Iran, Turkey or Syria. The objects are still a popular subject of research and have also become a part of the new decorative arts permanent exhibition of the museum that was opened in 2017.

Keywords: West Bohemian Museum in Pilsen, museum collection, museum history, Asian decorative art, Chinese art, Japanese art, Islamic art, exhibition, Josef Škorpil

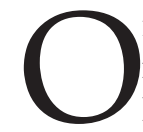
rientální podsbírka Západočeského muzea v Plzni byla formálně založena teprve na počátku 70. let 20. století. Přítomnost sbírkových předmětů pocházejících ze zemí asijského kontinentu je však zaznamenána již ve sbírkách předchůdců dnešní instituce. Tím bylo první plzeňské muzeum, tedy Obecní museum pro město Plzeň a západní Čechy založené v roce 1878 a především Západočeské umělecko-průmyslové museum v Plzni, založené v roce 1885 , které se po 2. světové válce stalo součástí dnešního muzea. ${ }^{1}$

Ačkoliv zaměření prvního plzeňského muzea bylo především regionální, již v jeho sbírce se objevovaly předměty "exotického" charakteru. Byly získávány převážně formou darů od soukromých osob a doplňovaly rychle se rozrůstající sbírku. ${ }^{2}$ Sbírka Západočeského umělecko-průmyslového musea v Plzni pak byla vytvořena na základě části sbírky Obecního musea. Prvním ředitelem umělecko-průmyslového musea byl jmenován architekt Josef Škorpil (1856-1931)³, který měl již zkušenosti ze Světové výstavy v Paříži v roce 1878, kde byl členem výstavní komise pro rakousko-uherskou expozici, nebo z pracovního pobytu v Petrohradu (stavební podnik Novikova, 1879-1883). Po návratu z Petrohradu se

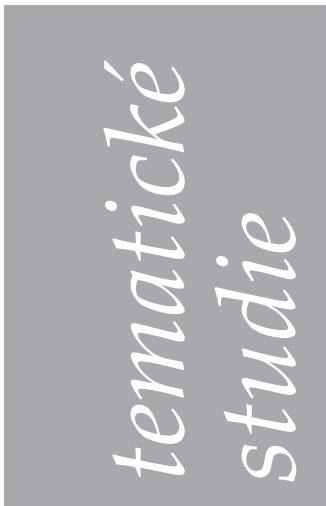

1 Západočeské umělecko-průmyslové museum vzniklo rozdělením Obecního musea pro město Plzeň a západní Čechy na dvě instituce. Tou druhou bylo Městské historické museum.

2 Např. dar "bosenské pušky (na kámen)" od c. k. setníka Jiřiho Kopeckého v Banja Luka $v$ Bosně a Hercegovině $v$ roce 1880 nebo japonské vějiřre a čínské hedvábí od p. Josefa Babičky ad. Viz Druhá zpráva Městského musea v Plzni za rok 1881. V Plzni: nákladem Musea, 1882, s. 10-12.

3 Josef Škorpil pocházel z Vysokého Mýta. Po absolvování gymnázia získal první stavitelské zkušenosti u firmy Schmoranz ve Slatiňanech. Studoval ve Vídni a na Vysokém učení technickém v Praze. Jeho dalši pracovní zkušenosti a doporučení historika umění Karla $B$. Mádla (1859-1932) mu zajistily pozici ředitele Západočeského umèlecko-průmyslového musea v Plzni. Ředitelem byl do roku 1922. (FRÝDA, František. Josef Škorpil. Architekt a ředitel Uměleckoprůmyslového muzea v Plzni. In: Krásný život žili, krásnou práci konali --: nejslavnější generace rodu Škorpilů. Vysoké Mýto: Regionální muzeum, 2006.)

Mgr. Jindřich Mleziva Uměleckoprůmyslové oddělení

Západočeské muzeum v Plzni

jmleziva@zcm.cz 


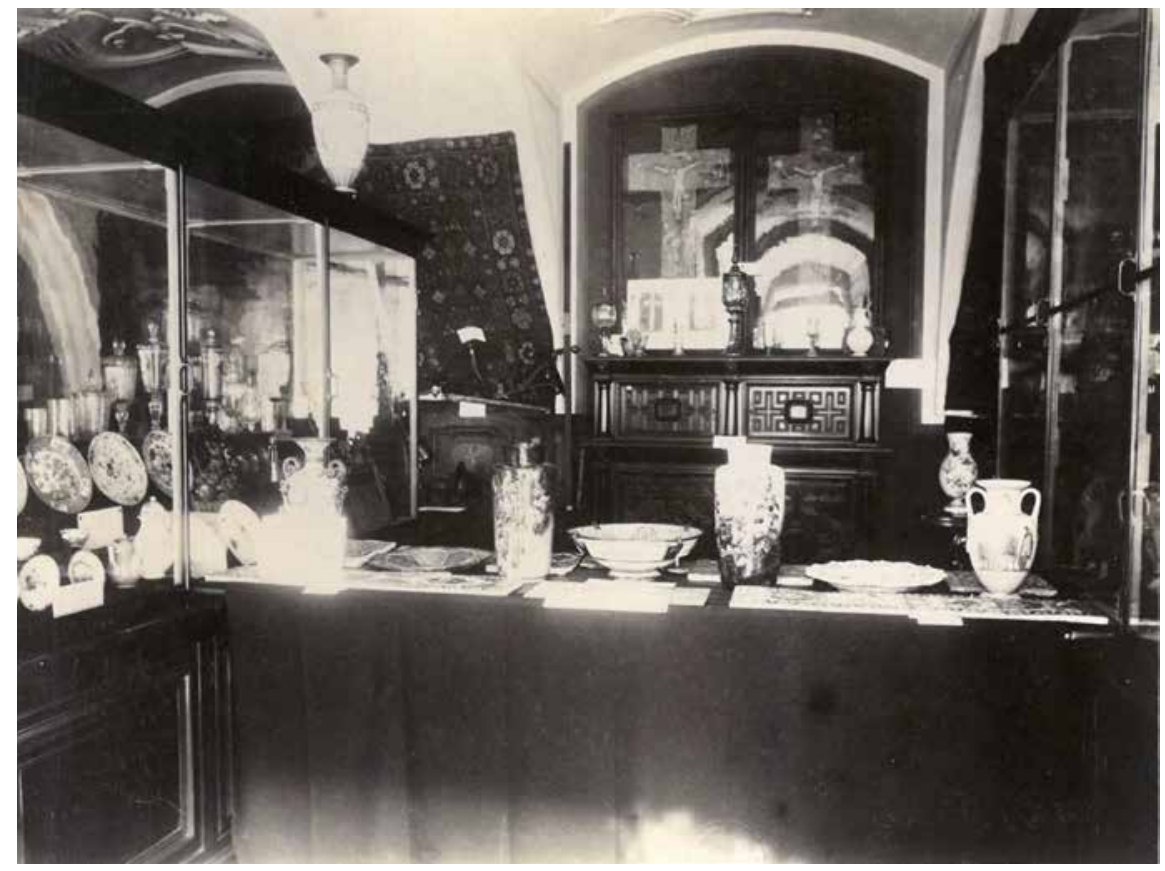

Pohled do expozice Obecního muzea pro město Plzeň ve Fodermayerově ulici v Plzni. (Nedatováno, Archiv ZČM v Plzni)

4 ČADÍK, Jindřich a ŠKORPIL, Václav. Bratři Škorpilové ve vzpomínkách. Pardubice: Východočeské muzeum, 1967,

s. 9.

5 Stavbou byla pověrena plzeňská firma stavitele Eduarda Kroha, štukovou výzdobu budovy provedl Celda Klouček (1855-1935), profesor na Uměleckoprùmyslové škole v Praze. Budova byla určena pro „Západočeské umělecko-průmyslové museum a Museum historicko-archeologické i prírodnické král. města Plzně" (ŠKORPIL, Josef a PETÁK, Václav. Západočeské umělecko-průmyslové museum císaře a krále Frant. Josefa I. v Plzni: výroční zprávy z roku 1892-1908. Plzeň: nákladem

Měst. uměl.-průmyslového

musea, 1908, s. 14). Josef

Škorpil také navrhl ve spolupráci s architektem Antonínem

Benešem výstavní mobiliár muzea, který pro uměleckoprůmyslové museum realizovala plzeňská firma František Lídl

a pražská firma Jan Navrátil (BERNHARDT, Tomáš. Oferta na dodání nábytku pro novou budovu muzejní v Plzni. Plzeň: Západočeské muzeum v Plzni, 1999 , s. 8). Vitríny od firmy Jan Navrátil jsou součástí expozice „Umělecké řemeslo / Užité umèní" otevřené v roce 2017. podílel na založení městského muzea v rodném Vysokém Mýtě. ${ }^{4}$ Josef Škorpil se kromě tvorby sbírky zasloužil i o podobu muzejní budovy, která byla realizována dle jeho návrhu. Hrubá stavba byla zahájena $\mathrm{v}$ roce 1897 a dokončena $\mathrm{v}$ roce $1901 .^{5}$ Do nové budovy se přemístily obě muzejní instituce a postupně se otevírala veřejnosti prostřednictvím veřejných přednášek a dočasných výstav ${ }^{6}$. Zprovozněna byla také knihovna a čítárna. ${ }^{7}$ Stálá expozice umělecko-průmyslového musea byla otevřena 13. července 1913 a návštěvníci zde mohli obdivovat i předměty z Asie nebo Balkánského poloostrova. Předměty byly zařazeny mezi ostatní (evropské) předměty dle materiálu a typu. Pouze vybrané čínské a japonské předměty byly soustředěny $\mathrm{v}$ jednom sále, $\mathrm{v}$ jehož čele stál japonský buddhistický oltář zuši

Vzorem pro vybudování sbírky a expozice uměleckoprůmyslového muzea se staly zahraniční instituce jako South Kensington Museum v Londýně (založeno v roce 1852, dnes známé jako Victoria and Albert Museum) ${ }^{8}$ nebo c. k. Muzeum umění a průmyslu ve Vídni ${ }^{9}$ (založeno $\mathrm{v}$ roce 1863). Mezi předchůdce plzeňského muzea v Čechách a na Moravě patřilo Uměleckoprůmyslové muzeum v Liberci (1873), Muzeum pro umění a průmysl v Brně (1873) nebo Uměleckoprůmyslové museum v Praze (1885). Samozřejmou součástí sbírek podobných uměleckoprůmyslových muzeí zakládaných ve 2 . polovině 19 . století byly předměty z Asie. Přítomnost asijských předmětů nebyla ovlivněna pouze velkou popularitou asijského (nebo tzv. orientálního) umění a řemesla v Evropě, ale také dlouhodobým a trvajícím vlivem asijského umění a řemesla na evropské umění a řemeslo. Plzeňské muzeum si se svým regionálním zaměřením a rozpočtem nemohlo dovolit výjimečné ukázky umělecko-řemeslné výroby z různých historických období. Do sbírky tak byly získávány různé př́íklady srovnávacích předmětů dle aktuálních nabídek a finančních možností, tak, aby doplnily uměleckoprůmyslovou sbírku jako celek. Koncept uměleckoprůmyslové sbírky se zaměřoval především na region západních Čech, ale nemohl pominout evropský kontext vývoje uměleckého řemesla s přesahem i do mimoevropských lokalit. $\mathrm{V}$ případě některých fondů je patrná snaha postihnout historii vývoje uměleckého řemesla až do období středověku (fond skla, keramiky a kovů) a plzeňské muzeum se může pochlubit také poměrně rozsáhlou antickou sbírkou. ${ }^{10}$ Předměty z dnešní orientální podsbírky vhodně doplnily historii vývoje výroby keramiky a porcelánu. Především to byly čínská a korejská keramika z 12. až 13. století nebo ukázky exportního čínského porcelánu od 17. století. Kromě financí však byly akvizice asijských předmětů omezeny i zdroji. Josef Škorpil však při tvorbě sbírky využil veškeré možnosti, které mu dané podmínky poskytovaly. Předměty nezískával pouze v Čechách, ale také během svých zahraničních cest - např. na světové výstavy do Paříže v roce 1889 a v roce 1900, nebo do zemí Balkánského poloostrova v roce 1910. V průběhu těchto cest získal řadu kontakti̊, od kterých i v následujících letech obdržel nabídky nových akvizic. Období do počátku 1. světové války je obdobím, kdy se do sbírky muzea dostal největší počet předmětů ze zemí asijského kontinentu a Balkánského poloostrova. Rozsáhlé akvizice $\mathrm{z}$ této doby jsou spojeny především s hamburskou firmou H. Saenger, která obchodovala s čínským a japonským uměním a uměleckým řemeslem. Spolupráce to byla velmi plodná a díky ní získalo muzeum velké množství 
předmětů z oblasti východní Asie a také řadu těch nejzajímavějších předmětů ve sbírce vůbec. Významná část kolekce pak byla vystavena ve stálé expozici muzea otevřené v roce 1913. Spolupráce $\mathrm{s}$ firmou $\mathrm{H}$. Saenger pokračovala několik let, prakticky až do 1 . světové války. Z bohaté korespondence mezi firmou a Josefem Škorpilem vyplývá, že i další muzea $\mathrm{v}$ českých zemích patrně získala předměty od stejné firmy. Josef Škorpil k odmítnutým nabídkám poskytl firmě H. Saenger kontakty na další možná muzea, která by mohla mít o předměty zájem. ${ }^{11}$ Tato redistribuce byla patrně běžná i v př́padě akvizic od jiných prodejců. Co do obsahu a charakteru sbírek asijského uměleckého řemesla, jsou plzeňské sbírce blízké např. sbírky Severočeského muzea $\mathrm{v}$ Liberci nebo Jihočeského muzea v Českých Budějovicích. ${ }^{12}$

Plzeňské muzeum spojuje s Budějovickým muzeem postava sochaře a medailéra (a př́tele Josefa Škorpila) Jindřicha Kautsche (1859-1943), který pracoval v Budějovickém muzeu jako konzervátor a později žil v Paříži a ve Vídni. ${ }^{13} \mathrm{~V}$ muzejním archivu je doložena bohatá korespondence mezi ním a Josefem Škorpilem, díky které se dozvídáme o značném množství akvizic sbírkových předmětů pro plzeňské muzeum zprostředkovaných Jindřichem Kautschem. Podobné předměty však nalezneme také ve sbírce Jihočeského muzea v Českých Budějovicích. ${ }^{14}$ Do sbírky přispěla i řada dalších významných osobností tehdejšího společenského života, jako byl cestovatel Enrique Stanko Vráz (1860-1932), Berta Feistmantelová (18531929), manželka geologa a paleontologa Otokara Feistmantela (1848-1891), nebo malíř Vojtěch Hynais (1854-1925).

Akvizice asijských předmětů po 1 . světové válce byly spíše př́ležitostné. Předměty asijského původu zůstaly i nadále součástí postupně se měnící stálé expozice, a to až do jejího uzavření na počátku 80 . let 20. století. Ačkoli se po 2 . světové válce asijskému umění a řemeslu $\mathrm{v}$ muzeu intenzívně nevěnoval žádný z kurátorů sbírky, její význam nebyl zpochybňován,

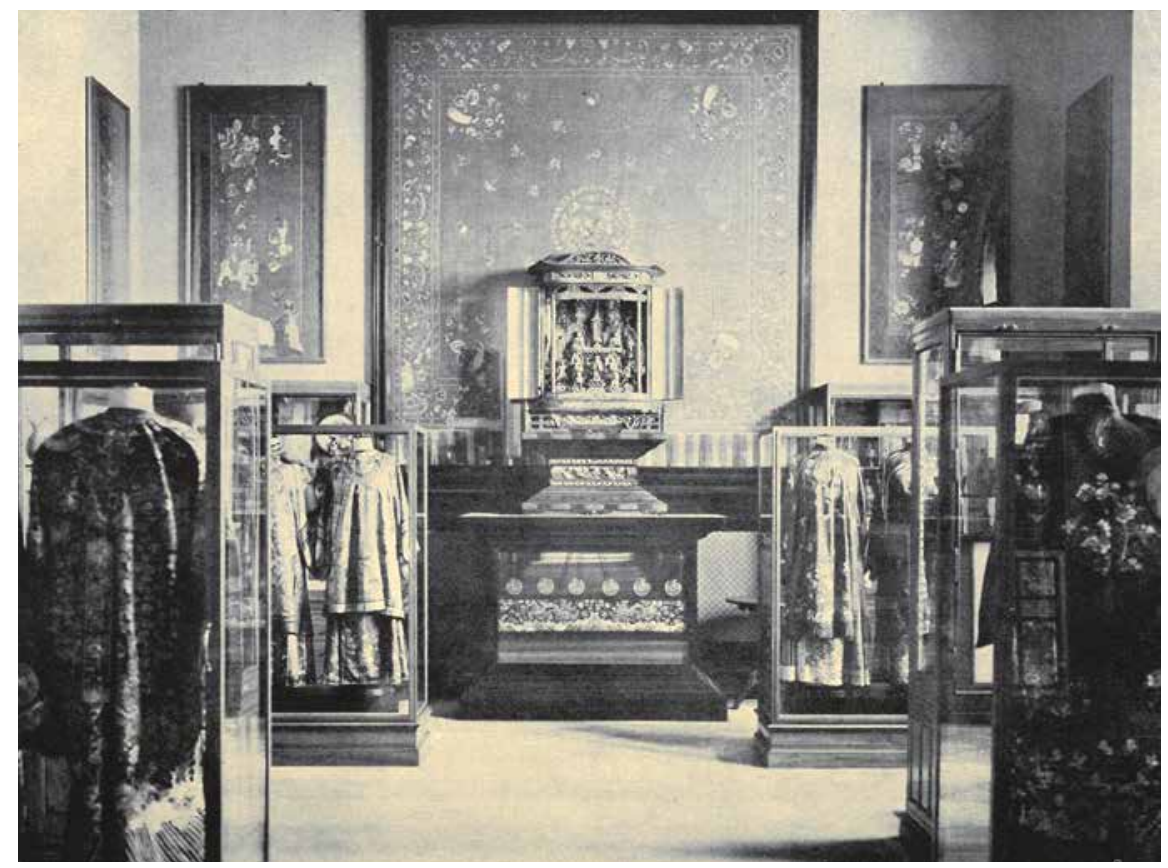

podobně jako $\mathrm{v}$ případě antické sbírky, kterou se intenzivně zabýval druhý ředitel muzea Jindřich Čadík (1891-1979). ${ }^{15}$ V roce 1970 byla vyčleněna samostatná tzv. orientální podsbírka, ${ }^{16}$ kam byly zařazeny především předměty $\mathrm{z}$ Číny a Japonska, částečně z Indie a Blízkého východu. $V$ zařazování předmětů do orientální podsbírky je patrná nedůslednost. Zatímco většina předmětů pocházejících z Číny a Japonska do podsbírky začleněna byla, předměty pocházející z jiných oblastí Asie (Indie, Střední Asie, Blízký východ) byly zařazeny jen částečně. $\mathrm{V}$ tomto členění není patrný žádný systém, proto lze předpokládat, že se tak dělo $\mathrm{z}$ důvodu nepř́tomností odborného kurátora se znalostí asijského uměleckého řemesla, který by při tvorbě podsbírky postupoval systematicky. Ǩada předmětů tak zůstala zapsána $\mathrm{v}$ uměleckoprůmyslové podsbírce. Zájem o předměty z orientální podsbírky byl oživen výstavu nazvanou „Orientální umění (ze sbírek uměleckoprůmyslového oddělení)“17, kde byl představen reprezentativní výběr předmětů. Stálá expozice $\mathrm{v}$ té době již nedosahovala původního rozsahu a na počátku 80 . let byla uzavřena spolu s celou muzejní budovou $\mathrm{z}$ důvodu dlouhodobé rekonstrukce. Z tohoto zásahu do provozu muzea a jeho veřejné činnosti se instituce vzpamatovává dodnes. Se stálou expozicí zmizela z očí veřejnosti také orientální podsbírka. První samostatné výstavy s asijskými předměty se začaly pořádat od konce 20 . stoletín ${ }^{18}$ a nová
Pohled do expozice Západočeského umělecko-průmyslového musea otevřené $v$ roce $1913 \mathrm{~s}$ japonským buddhistickým oltářem a čínskými textiliemi. (Nedatováno, Archiv ZČM v Plzni)

6 Muzeum pořádalo a podílelo se na mnoha výstavách pořádaných $v$ budově muzea i mimo ni. Stejně tak bylo pořadatelem mnoha odborných přednášek a kurzů. (Viz např. ŠKORPIL, Josef a PETÁK, Václav. Západočeské umělecko-průmyslové museum císaře a krále Frant. Josefa I. v Plzni: výroční zprávy z roku 18921908. Plzeň: nákladem Měst. uměl.-průmyslového musea, 1908.) Např. výstava uměleckých výšivek národů slovanských (1903), výstava prací žáků c. k. umělecko-průmyslových a odborných škol rakouských, které byly vystaveny na světové výstavě v St. Louis (1906), prednáška Renaty Tyršové "O umění vyšivacím" (1903), J. Maška "O novém slohu v zlatnictví, o drahokamech a jich napodobeninách, o českém granátu a šperku granátovém" (1906) a mnohé další.

7 Čítárna byla otevřena 1. ledna 1906 (ŠKORPIL, Josef a PETÁK, Václav. Západočeské umělecko-průmyslové museum císaře a krále Frant. Josefa I. v Plzni: výroční zprávy z roku 1892-1908. Plzeň: nákladem Měst. uměl.-prưmyslového musea, 1908, s. 75). 


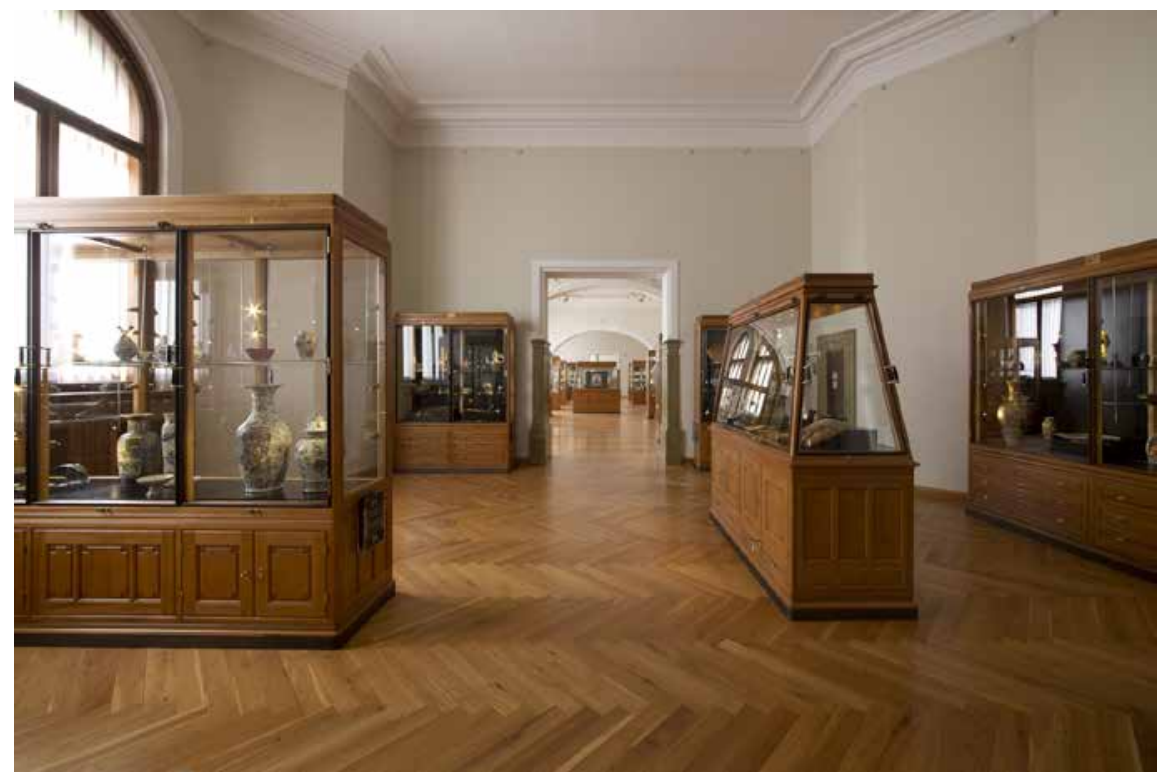

Pohled do expozice „Umělecké řemeslo / Užité uměni" otevřené v roce 2017. (Foto: Václav Marian)

8 ČADÍK, Jindřich a ŠKORPIL, Václav. Bratři Škorpilové ve vzpomínkách. Pardubice: Východočeské muzeum, 1967,

s. 10.

9 k.k. Österreichisches Museum für Kunst und Industrie, dnešni Museum für angewandte Kunst (MAK).

10 Velká část antické sbírky pochází z nálezů archeologa, filologa a ředitele Archeologického muzea v Kerči Vladislava Škorpila (1853-1918), především ze starověkého Pantikapaia na Krymu. Sbírka byla doplněna nákupy od evropských starožitníků.

11 Opis dopisu H. Saengerovi ze dne 11. května 1903 (Archiv ZČM v Plzni, 1902-03, kniha č.

54).

12 Jak již bylo zmíněno výše, Severočeské muzeum v Liberci bylo založeno $v$ roce 1873 jako uměleckoprůmyslové muzeum. Jihočeské muzeum v Českých Budějovicích bylo založeno $v$ roce 1877.

13 Jindřich Kautsch studoval na zlatnické škole a uměleckoprůmyslových školách v Praze a Vídni, podnikl radu studijních cest po Evropě. Od roku 1887 pracoval v muzeu $v$ Českých Budějovicích, kde reorganizoval sbírky. Zde také vydal knihu Goldschmiede-Arbeiten des

XVI. und XVII. Jahrhundertes und der Neuzeit (1889).

Od roku 1889 se usadil v Pařiži a spolupracoval na prípravě Světové výstavy v roce 1900. uměleckoprůmyslová expozice byla otevřena teprve v listopadu 2017. Její součástí se stalo umělecké řemeslo Blízkého a Dálného východu. Posledními rozsáhlými akvizicemi asijských předmětů byl soubor předmětů z Tibetu a Číny od soukromého sběratele, plzeňského rodáka MUDr. Vladimíra Piskáčka, a soubor japonských autorských laků Kjósy Suguriho (1909-2003). ${ }^{19}$

Asijské umělecké řemeslo ve sbírce uměleckoprůmyslového oddělení Západočeského muzea $\mathrm{v}$ Plzni lze bez ohledu na zařazení předmětů do orientální nebo uměleckoprůmyslové podsbírky rozdělit geograficky na fond předmětů čínských, japonských, indických a předmětů z jihovýchodní Asie a Blízkého východu.

\section{Korejská a čínská sbírka ${ }^{20}$}

Většina předmětů ve sbírce pochází z 19. století, především pak z jeho druhé poloviny. Do sbírky se však podařilo získat i řadu starších předmětů. Patří sem především významné ukázky dokumentující vývoj keramiky a porcelánu v Asii. Tyto předměty dokládají oblibu podobných výrobků v Evropě, kde se s nimi v 19. století čile obchodovalo. Nejstaršími jsou tzv. seladonové nádoby pocházející z období korejské dynastie Korjo (9181392). Keramika s typickým šedozeleným odstínem glazury je bez výzdoby nebo je zdobena rytým, řezaným, tlačeným či inlejovaným dekorem pod glazurou. Tyto ukázky jsou doplněny o několik výrobků pocházejících z období čínských dynastií
Severní Sung (960-1127), Ming (13681644) a Čching (1644-1911). ${ }^{21}$

Část porcelánových výrobků pochází z doby vlády dynastie Ming, převážná část keramiky a porcelánu má původ v období vlády dynastie Čching a jedná se o výrobky určené pro export do Evropy. Ve sbírce tak nalezneme několik ukázek ze 17. století, početnější je ale skupina porcelánových nádob z 18. století. Jedná se o nádoby zdobené barevnými emaily (ve stylu famille rose a famille verte) nebo bílý porcelán bez výzdoby (tzv. blanc de Chine). Řada těchto předmětů byla získána nejen od firmy H. Saenger, ale také od dalších starožitnických firem v zahraničí i v Čechách. Ačkoliv se jedná převážně o běžnou exportní produkci, nalézají se ve sbírce typologicky zajímavé předměty, jako je např. nádobka kendi (inv. č. O/107).

Nádoba na vodu zvaná kendi (inv. č. O/107) pochází z 2. poloviny 16 . století. Tento typ nádoby je starověkého původu ${ }^{22}$, vyráběla se z keramiky a rozšíríla se po celé východní a jihovýchodní Asii. V Číně se vyráběly také porcelánové varianty, které se vyvážely i do Evropy. Nádoby kendi se od 16. století objevují na evropských olejomalbách jako dekorativní předměty. ${ }^{23} \mathrm{Na}$ těchto starších pracích si můžeme všimnout oblíbené úpravy nádoby pomocí kovových montáží a její adaptace v novém prostředí. V Evropě se $\mathrm{z}$ ní mohla stát konvice, v zemích Blízkého východu to byla nádoba vodní dýmky. $K$ této úpravě se používaly slitiny mědi nebo stříbro. Bronzové montáže aplikované na (nejen) asijský porcelán byly v Evropě ve velké oblibě i v 19. století. $^{24}$

Velkou skupinu předmětů tvoří čínský textil. Většina ukázek byla získána od dvou firem - H. Saenger z Německa a Feifalik z Rakouska. Dalšími výšivkami byla sbírka doplněna od soukromých osob, jako např. od cestovatele a spisovatele Enrique Stanko Vráze (1860-1932) nebo malíře Vojtěcha Hynaise (18541925). Sbírka čínského textilu byla vytvořena $v$ relativně krátké době na přelomu 19. a 20. století $^{25}$ a obsahuje práce 
především z konce 19. století. Ve sbírce, podobně jako $\mathrm{u}$ předmětů $\mathrm{z}$ jiných lokalit, bylo záměrem ukázat techniky uměleckořemeslného zpracování textilu, $\mathrm{v}$ tomto případě výšivky hedvábím s použitím dalších materiálů. Sbírka tak obsahuje části oděvů, především bohatě vyšívaná hedvábná roucha, jako tzv. Dračí roucho, formální oděv úředníka-učence u dvora dynastie Čching, a mnoho ozdobně vyšívaných nebo tkaných fragmentů, včetně rukávových výšivek nebo vyšívaných odznaků úřední hodnosti ad. Sbírka také odráží zájem o určitý typ předmětů $\mathrm{v}$ Evropě a jejich prezentaci v novém prostředí. ${ }^{26}$

Mezi oděvní doplňky ve sbírce patří ukázka třinácti převážně exportních pevných a skládacích vějiŕru z období od 30. let 19. století do 1 . poloviny 20. století. Vějiřre mají konstrukci dřevěnou nebo ze slonoviny a listy jsou hedvábné a papírové, zdobené výšivkou a malbou. Čínskou část sbírky doplňuje několik kovových předmětů zdobených technikou přihrádkového a jamkového emailu, šperků $\mathrm{z}$ konce 19. století, lakových předmětů či prací ze dřeva.

$\mathrm{V}$ roce 1999 získalo muzeum darem ${ }^{27}$ soubor tibetských a čínských, zejména rituálních a votivních předmětů spjatých s náboženstvím Bön a tibetským buddhismem. Patř́ sem řada drobných kovových (bronzových) plastik, rituálních zbraní, ceremoniální misky z kosti doplněné ozdobným tepaným kovem nebo thangky malované na šepsovaném plátně. Součástí daru jsou i šperky nebo jednoduché soustružené dřevěné zásobnice.

\section{Japonská sbírka}

Chloubou japonské sbírky a sbírky muzea vůbec je přenosný buddhistický oltář zuši (inv. č. O/1), který zároveň patři mezi nejvýznamněǰsí akvizice od firmy H. Saenger. Historie oltáře je dnes díky rozsáhlému badatelskému průzkumu částečně známa. ${ }^{28}$ Oltář vyrobil $\mathrm{v}$ roce 1802 buddhistický mnich Hajaši Njozui VII. v Kjótu. Přenosný oltáŕ zuši ${ }^{29}$ pochází z východní cásti Kjóta, z kláštera

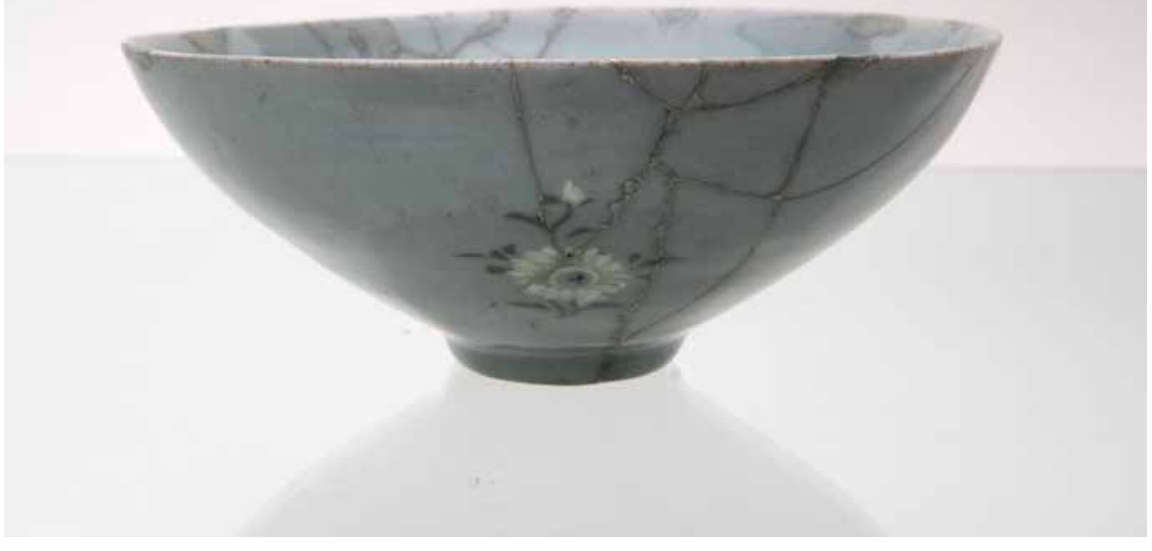

Honkokudži a je spojen s Ničirenovou sektou, jednou z nejdůležitějších buddhistických škol v Japonsku. ${ }^{30}$ Třináct postav v oltáři zuši je soustředěno kolem centrální pagody s invokací „Namu mjóhó rengekjó“ („Vzývám vzácnou Lotosovou sútru“). Po obou stranách pagody jsou sošky Buddhů, v jednotlivých rozích jsou umístěni Čtyři nebeští králové Šitennó a v prostoru jsou další postavy Buddhů a bódhisattvů. Ve spodní části je děsivě vyhlížející ústřední postava celého oltáře modlící se bohyně/démon Kišimódžin ${ }^{31}$ umístěná mezi sošky bódhisattvy Fugena

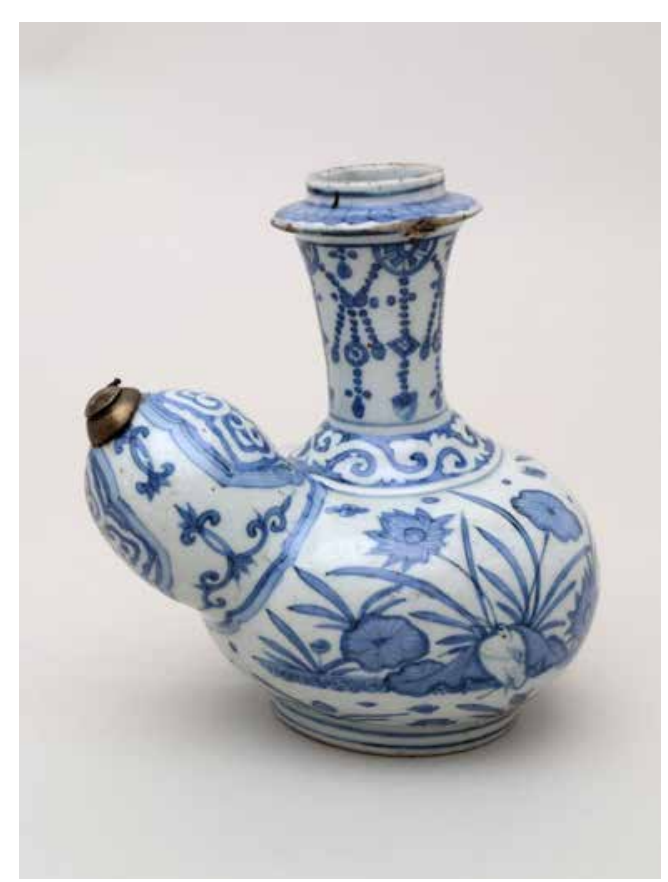

Nádoba kendi. Čína, 2. polovina 16. století. Porcelán, kov, malba kobaltem pod glazurou. Rozměry: v. $17 \mathrm{~cm}$. Inv. č. O/107.
Miska. Korea, 12.-13. století, dynastie Korjo (9181392). Kamenina, inlejovaná výzdoba. Rozměry: v. $6,7 \mathrm{~cm}$, prům. $16 \mathrm{~cm}$. Inv. č. O/51. (Foto: Ivana Michnerová)

$\checkmark$ roce 1914 se prestěhoval do Vídně. (Österreichisches Biographisches Lexikon und biographische Dokumentation [online]. Österreichischen Akademie der Wissenschaften, 2003-2018 [cit. 14.10.2010]. Dostupné z: https://www. biographien.ac.at/oebl/oebl_KI Kautsch_Heinrich_1859_1943. xml;internal\&action=hilite. action\&Parameter $=$ kautsch $*$ ) 14 Jedná se především o analogické mosazné práce původem z Íránu z 19. století. 15 Jindřich Cadík pracoval $\checkmark$ muzeu s vynucenými prestávkami do 70. let 20. století. Studoval klasickou archeologii, filologii a dějiny umění na Filosofické fakultě české Karlo-Ferdinandovy univerzity v Praze. Od roku 1917 byl knihovníkem Západočeského umělecko-průmyslového musea v Plzni. Reditelem se stal $v$ roce 1923. $V$ roce 1944 byl zatčen gestapem a odsouzen $k$ trestu smrti. Od konce války do roku 1948 byl opět na pozici ředitele muzea. $V$ roce 1950 byl zatčen a odsouzen $k 20$ letům vězení. Propuštěn byl $v$ roce 1959 a $v 60$. letech se vrátil zpět do muzea. $V$ roce 1970 spolupracoval na výstavě Národního muzea "Antické sklo z československých sbírek" doprovozené katalogem. (ČADÍk, Jindřich. Antické sklo: prưvodce výstavou v Národním 


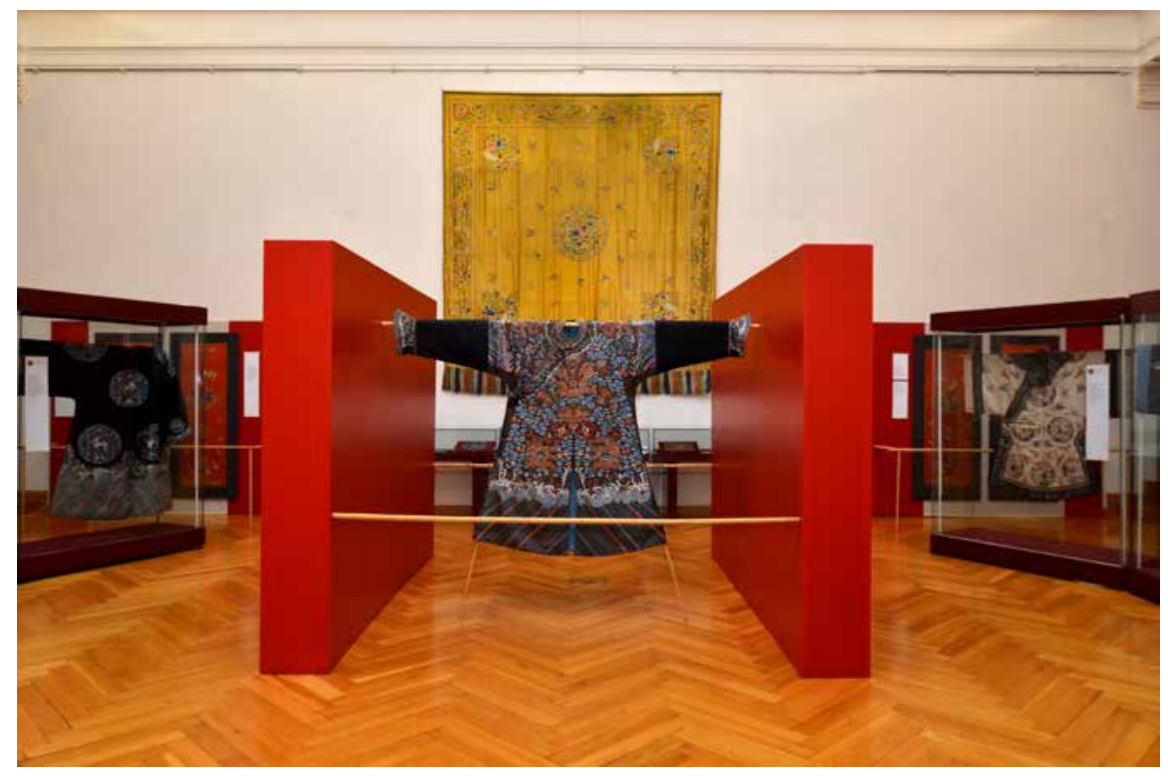

Pohled do výstavy „Draci a Pivoňky. Čínský textil ve sbírce Západočeského muzea v Plzni" (prosinec 2016-únor 2017). (Foto: Ivana Michnerová)

muzeu v Praze. Praha: Národní muzeum, 1970. $\check{R} E H O \check{R}$, Vit. Historik Jindřich Čadík - životní osudy a dílo [online].

Plzeň, 2012 [cit. 2019-10-15].

Dostupné z: <https://theses.cz/ id/en0jdm/>. Diplomová práce. Západočeská univerzita v Plzni, Fakulta pedagogická.) 16 Založení prírưstkové knihy je datováno 3. 1. 1970 a prvním zapsaným predmětem je "Budhistický vyřezávaný oltář" pod inv. č. O/1 (Inventární kniha Orient I, uměleckoprümyslové oddělení Západočeského muzea v Plzni).

17 Výstava se konala v srpnu až prosinci 1979.

18 „Tibet” (1999), „Orientální uměni" (květen 2004 - únor 2005), "Zlatý věk ukiyoe" (2005), „Kjósa Suguri Kjósabori" (2007), "Katagami" (2009) nebo „Draci a Pivoňky. Cínský textil ve sbírce Západočeského muzea v Plzni" (prosinec 2016 - únor 2017).

19 Dar byl zprostredkován panem Eišinem Haradou, predsedou Japonské zahradnické asociace $v$ Tokiu, autorem japonské zahrady Šówa-en $v$ Zoologické a botanické zahradě města Plzně.

20 Oficiálně jsou všechny předměty součástí jedné sbírky Západočeského muzea v Plzni, jejímž vlastníkem je Plzeňský

$k r a j$, a ta je dále dělena na podsbírky (viz Centrální evidence sbírek muzejní povahy), na bílém slonu a Mondžua na modrém lvu. Oltář obsahuje další skryté nápisy včetně „ita mandary“, kaligrafické mandaly vyryté do dřevěné desky $v$ kopii Ničirenovy kaligrafie. Na postavách jsou pozdější nápisy, které dokládají restaurování oltáře na počátku 50. let 19. století, v chrámu Ondžuin. ${ }^{32}$ Jeho další historie a cesta do Evropy však dosud není objasněna.

Do okruhu buddhistických předmětů patří i tři dřevěné plastiky, tzv. Amidova trojice (inv. č. O/16, O/17, O/18), kterou

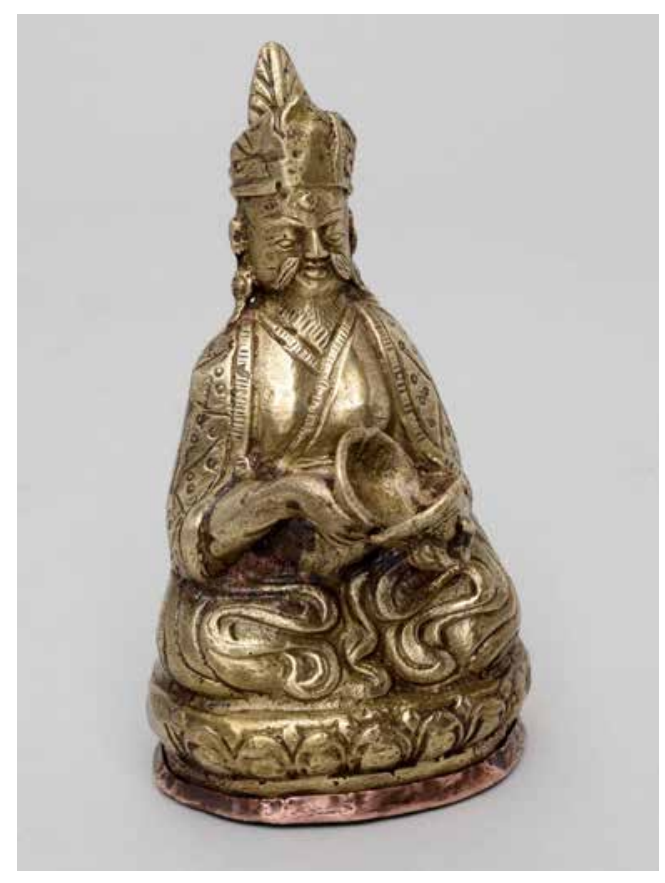

Soška sedícího ňingmapovského učence. Nepál, 19. - počátek 20. století. Litá mosaz, měd'. Rozměry: v. $13 \mathrm{~cm}$. Inv. č. O/1279. (Foto: Ivana Michnerová) tvoří Buddha Amida (skrt. Amitábha), Kannon (skrt. Avalókitéšvara) - bódhisattva milosrdenství a soucitu, Seiši (skrt. Mahásthámaprápta) - bódhisattva síly moudrosti. Sousoší bylo získáno od firmy H. Saenger z Hamburku v roce 1908. Podle dochované faktury firmy H. Saenger, získal trojici soch majitel firmy přímo $\mathrm{v}$ Japonsku. ${ }^{33}$ Do této skupiny patří také dvě menší plastiky bódhisattvů Džizó, jedna s polychromií a jedna zlacená. U sošky zlaceného Džizóa (inv. č. O/204) je v podstavci tuší psaný autorský nápis a zjištłujeme tak, že dílo pochází z Kjóta a bylo vytvořeno $\mathrm{v}$ roce $1687 .{ }^{34}$

Do japonského souboru patří také exportní keramika a porcelán z 18. a 19. století, kovové práce především z 19. století (např. plastiky, součásti chladných zbraní), drobné dekorativní předměty ze slonoviny (necuke, okimono) nebo výrobky ze dřeva s povrchem zdobeným laky.

Význačný soubor tvoří skupina přibližně 340 grafických listů převážně z vrcholného období japonského dřevořezu poslední třetiny 18 . století a 1 . třetiny 19 . století a zahrnující nejvýznamnější umělce jako je Utagawa Tojokuni, Hirošige, Šunšó, Kunisada nebo Hokusai. Jelikož převážná většina dřevořezů nebyla nikdy vystavována, zachoval se původní barevný vzhled tisků. Většina dřevořezů byla získána od starožitníků v Lipsku (Karel Wilhelm Hiersemann) a Frankfurtu (Joseph Baer et Comp.) na počátku 20. století. Další jednotlivé dřevořezy byly získávány $\mathrm{v}$ průběhu 20. století.

\section{Indie a jihovýchodní Asie a zemè Blízkého východu}

Tato část sbírky sice vznikala ve stejné době jako čínská a japonská, ale akvizice nebyly natolik rozsáhlé a jednalo se spíše o menší skupiny předmětů nebo jednotlivosti. Předměty pak byly součástí fondů členěných dle materiálu, což se promítlo i do jejich prezentace ve stálé expozici otevřené v roce 1913, ale i později při tvorbě orientální podsbírky v 70. letech 
20. století, kdy mnohé předměty zůstaly zařazeny $\mathrm{v}$ jednotlivých fondech na základě materiálu.

Soubor předmětů z Indie a jihovýchodní Asie působí nevyrovnaně zřejmě také proto, že byl sbírán nesystematicky. Přibližně stovka sbírkových předmětů zahrnuje především indické kovy z 19. a 20. století určené pro export, nebo př́mo suvenýry (uttarpradéšské nádoby zdobené mosazí a lakem, např. pohár inv. č. O/1008, nebo kašmírské nádoby zdobené barevnými emaily, např. konvice inv. č. O/1026), objevují se zde drobné lité plastiky z jihovýchodní Asie (např. thajský sedící Buddha z litého a zlaceného bronzu, inv. č. O/229), zbraně (indický zulfikar, inv. č. O/1097, reprezentativní kris s pochvou, inv. č. UMP 4848) nebo ukázky grafiky (hinduistické miniatury, inv. č. O/259 - O/266). Mezi suvenýry, které se vyrábějí v podobném provedení až dodnes, lze zařadit alabastrový

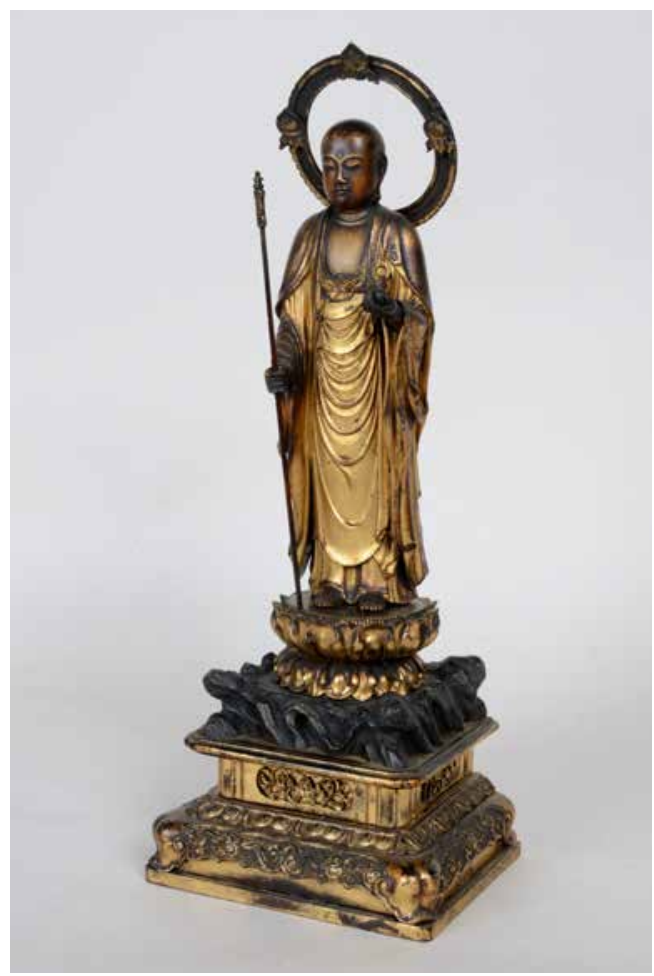

Bódhisattva Džizó. Kjóto, Japonsko, 1687. R̆ezba ve dřevě (hinoki) zdobená zlatým lakem a lakovou polychromii. Rozměry: v. $41 \mathrm{~cm}$. Inv. č. O/204. (Foto: Ivana Michnerová)

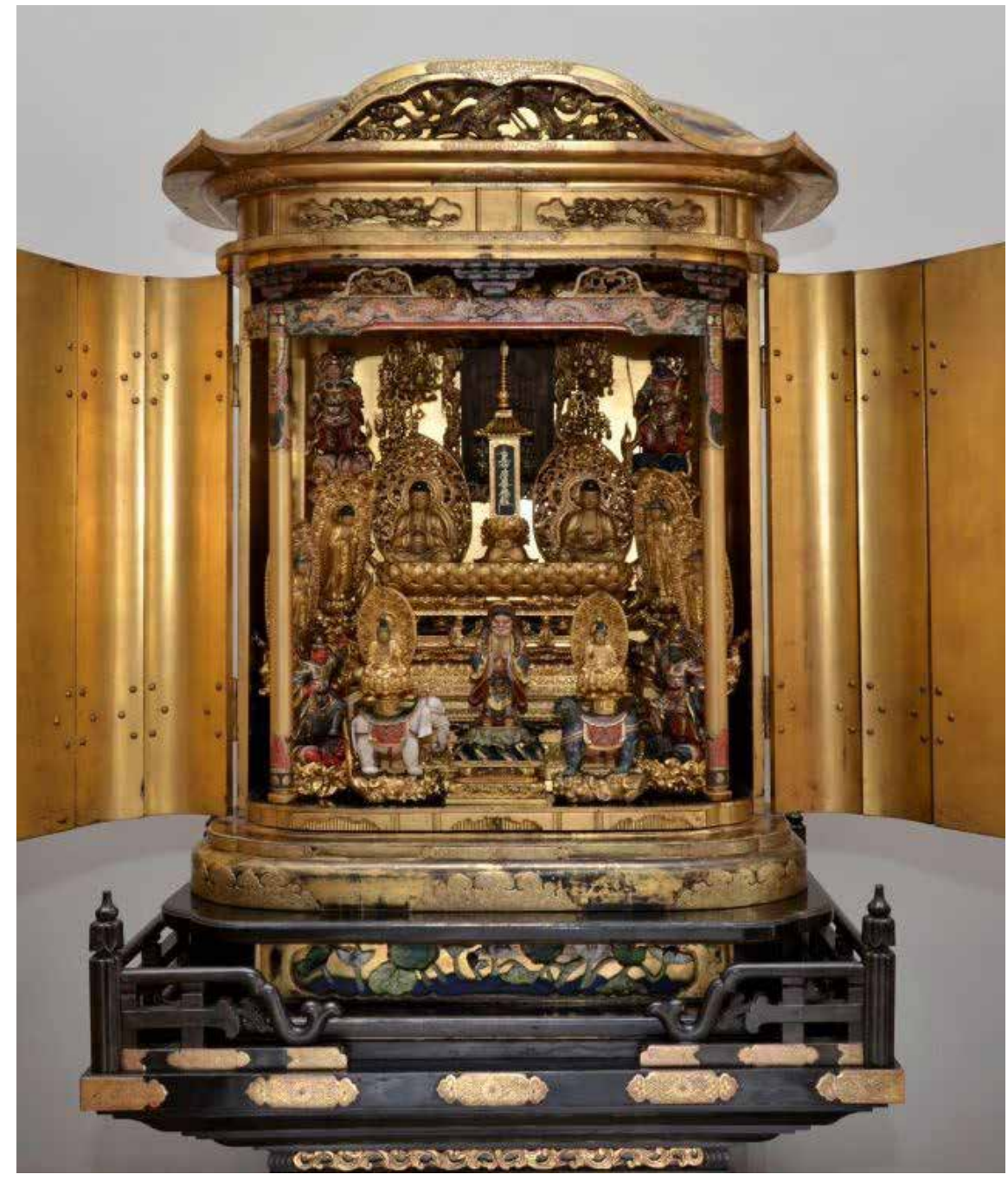

model hrobky Tádž Mahal pocházející z počátku 20. století (inv. č. O/1096).

Také $\mathrm{v}$ př́ípadě souboru předmětů pocházejících ze zemí Blízkého východu a Střední Asie proběhla většina akvizic na na konci 19. století a na počátku 20. století. V menší míře pak byly předměty získávány v průběhu 20. století a fond je doplňován do současnosti.

Nejpočetnějším souborem této části sbírky jsou výrobky z kovu. Především se jedná o předměty $z$ mědi a jejích slitin a železa, pocházející z 18. a 19. století. Nejstarším předmětem je nádoba na potraviny z 2 . poloviny 15 . století pocházející z Egypta nebo Sýrie (inv. č. UMP 4864), kdy byla tato oblast pod nadvládou Mamlúků (1250-1517). Mísa je vyrobena z mědi a víko $\mathrm{z}$ mosazi ${ }^{35}$, obojí je pocínováno a zdobeno rytým geometrickým a rostlinným dekorem s blahopřejnými nápisy. Součástí dekoru jsou i mamlúcké erby s titulem dawádár (kancléŕ) se symbolickým zobrazením tohoto statutu v podobě otevřeného pouzdra na psací potřeby
Buddhistický oltár

Daikózan zuši. Hajaši Njozui VII., Kjóto, Japonsko, 1802. Řezba ve dřevě, polychromie, lak, zlacené dřevo, zlacené kování z mědi. Rozměry: (skřín) v. $111 \mathrm{~cm}$, š. $63 \mathrm{~cm}$, d. $77 \mathrm{~cm}$. Inv. č. O/1. (Foto: Ivana Michnerová)

$v$ rámci uměleckoprůmyslového oddělení pak na jednotlivé fondy. Terminologie je $v$ textu zjednodušena a souhrnně je používáno termínu "sbírka” i v prípadě podsbírek a fondů. 21 Tři předměty mají doložený pưvod $v$ dokladech od firmy H. Saenger (Inv. č. O/51, O/52, O/137), původ ostatních predZtráta původních informací patrně souvisí s novými zápisy předmětů po 2. světové válce. 22 „Kundika” ze sanskrtu. 23 Např. na obrazu "Alegorie zraku" (1617) Petera Paula Rubense (1577-1640) a Jana Brueghela staršího (1568-1625) mětů ve sbírce není uveden. 
(Museo del Prado, Madrid, inv. č. P001394) nebo s kovovou montáží v "Zátiší" od Pietera Gerritsze van Roestratena (1630-1700) (soukromá sbírka). 24 Pro tyto účely se také využívaly repliky asijské keramiky a porcelánu, jak dokládá např. výroba pařižšé firmy Samson.

Ta se specializovala na výrobu kopií asijské a evropské keramiky a také na výrobu bronzových montáži použitých na vlastnich výrobcích (SLITINE,

Florence. Samson, génie de I'imitation. Paris: Massin, 2002).

25 Rozsáhlejší akvizice z pozdějšího období pochází od Ludmily Lábkové (19021987), manželky zakladatele Národopisného muzea Plzeňska Ladislava Lábka (1882-1970).

26 Např. hedvábné vyšivané povlaky na židle jsou ve sbírce instalovány jako interiérové dekorace (inv. č. O/980, O/985 ad.).

27 Soubor téměř osmdesáti předmětů daroval muzeum plzeňský rodák MUDr. Vladimír Piskáček (nar. 1929).

28 Výzkum provedla $v$ souvislosti s restaurováním oltář v Národní galerii Praha japanoložka PhDr. Helena Honcoopová (HONCOOPOVÁ, Helena. The Puzzle of the Kishimojin altarpiece from Pilsen. In: Sborník Západočeského muzea v Plzni. Historie. Plzeň: Západočeské muzeum v Plzni, 2020. (v tisku). 29 Malá buddhistická svatyně nebo domácí (přenosný) oltár $v$ podobě skřínky.

30 Ničiren Šónin (1222-1282) byl buddhistický mnich, jehož učení klade důraz na Lotosovou sútru jako jedinou správnou cestu ke spáse lidstva.

31 Hinduistická matka démonů Hárítí, v buddhismu ochránkyně dětí, snadného porodu, rodičovství ad. (KRAEMEROVÁ,

Alice a GAUDEKOVÁ, Helena.

Buddhové, bódhisattvo-

vé a božstva: buddhistické umění v japonské sbírce

Náprstkova muzea = Buddhas, Bodhisattvas and Deities: Buddhist Art in the Japanese Collection of the

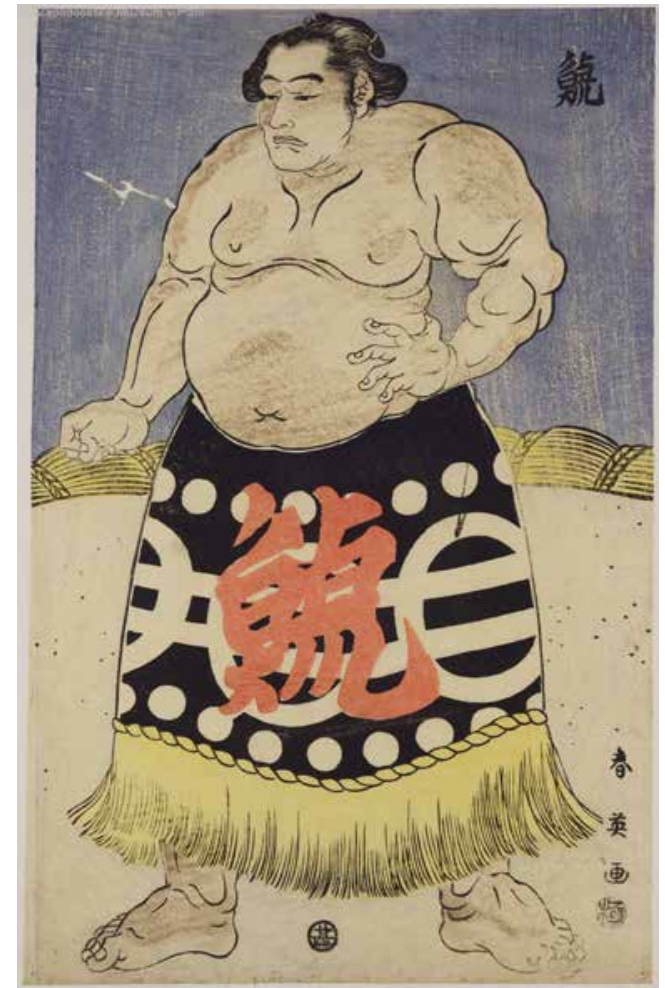

Zápasník sumo Tora. Kacukawa Šun'ei, Japonsko, ca 1800. Dřevořez, tisk z výšky. Rozměry: v. $33 \mathrm{~cm}$, š. $21,2 \mathrm{~cm}$. Inv. č. $0 / 750$. (Foto: Ryo Akama) ve středu medailonu, a džamdár (pán šatníku), tedy čtverce zobrazující ubrousky. Nádoba byla zakoupena od Jindřicha Kautsche v roce 1901, tedy v době, kdy žil v Paříži, a byla zaslána do Plzně s několika dalšími předměty. Předmět byl původně určen jako turecký, z 18. století. Kromě výzdoby jsou zde vyryty i kurzívní nápisy odkazující na autora a majitele nádoby. Provedení odpovídá pozdnímu mamlúckému období. Plzeňská mísa je jednou z variant nádoby na potraviny mohly být jiného profilu nebo složené z několika mís nad sebou, i z jiného materiálu. ${ }^{36}$ Podobné nádoby se vyráběly také z mosazi a používaly se ve Středomoří i později za vlády Osmanů.

Součástí sbírky jsou další oblíbené výrobky z 19. století, jako mosazná vykuřovadla, lampy nebo mísy, talíre a podnosy s rytou a prolamovanou výzdobou. Zajímavostí jsou dvě volné plastiky - páva a slona (inv. č. UMP 4836 a UMP 4842) - vyrobené $\mathrm{z}$ oceli a zdobené stř́brem a zlatem. Ačkoliv se plastika v podobě lidských postav nebo zvířat v umění zemí s dominujícím islámským náboženstvím

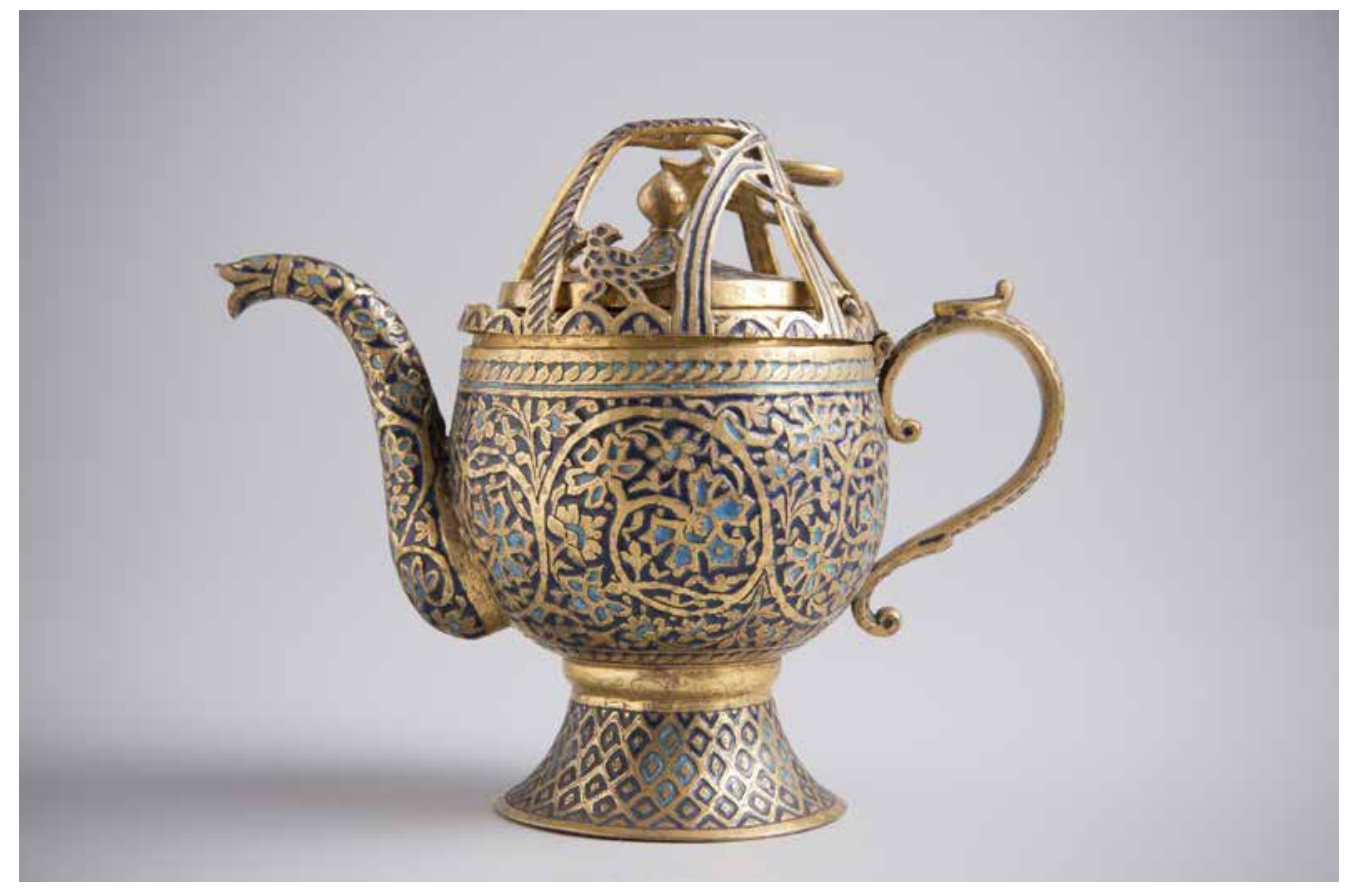

Čajová konvice. Kašmír, Indie, konec 19. století. Zlacená měd', barevné emaily. Rozměry: v. $15 \mathrm{~cm}$, prưm. $10 \mathrm{~cm}$. Inv. č. O/1026. (Foto: Václav Marian) 
a z něj vyplývajícími předpisy objevuje, nikdy nebyla běžná $v$ takové míre jako v křestanské Evropě a často měla nějaký účel (konvice, vykuřovadlo, součást fontány apod.). Typ ocelové plastiky, kam patři plzeňské, pochází z Íránu, kde bylo zobrazování živých bytostí v umění běžnější. Tyto plastiky mohly být skutečně pouhými dekorativními předměty, používaly se však také pro ozdobu standard používaných během šíitského svátku ašúrá $\mathrm{v}$ měsíci Muharram. Vynikající řemeslné práce Střední Asie zastupuje konvice na čaj z Buchary v dnešním Uzbekistánu z 2. poloviny 19. století (inv. č. UMP 4856). ${ }^{37}$ Sbírka obecně zahrnuje typické ukázky z různých regionů především Osmanské říše a Íránu z 18. a 19. století. Spíše než o výjimečné práce se jedná o ukázky různých typických technik zpracování a zdobení kovů $\mathrm{v}$ tomto období - např. žárové zlacení s použitím rtuti tzv. tombak ${ }^{38}$, známé z osmanského prostředí, prolamování typické nejen pro íránská vykuřovadla apod.

Josef Škorpil získal poměrně málo předmětů ze zemí Blízkého východu, ale jednalo

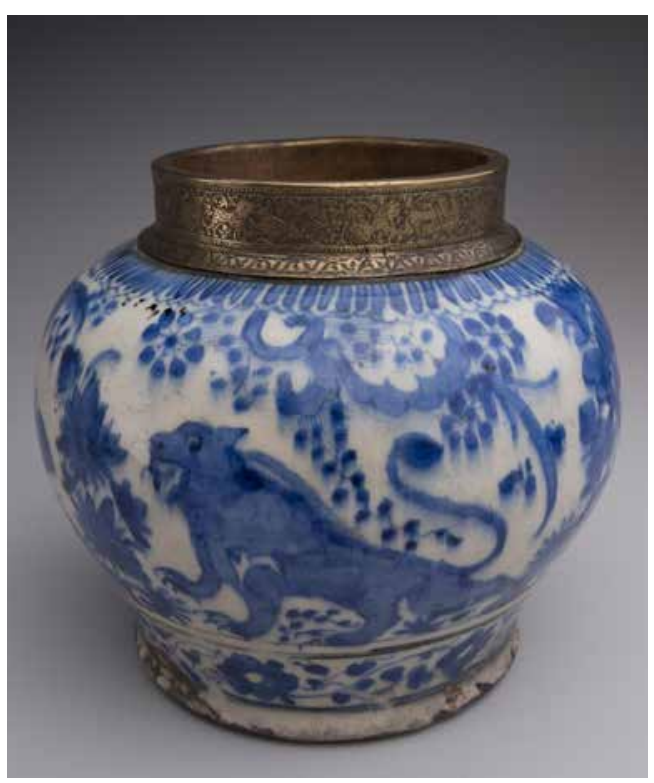

Váza. Írán, 17. - 19. století. Fritová keramika, malba pod glazurou, mosaz. Rozměry: v. $16,7 \mathrm{~cm}$, prüm. $17 \mathrm{~cm}$. Inv. Č. O/55. (Foto: Václav Marian)

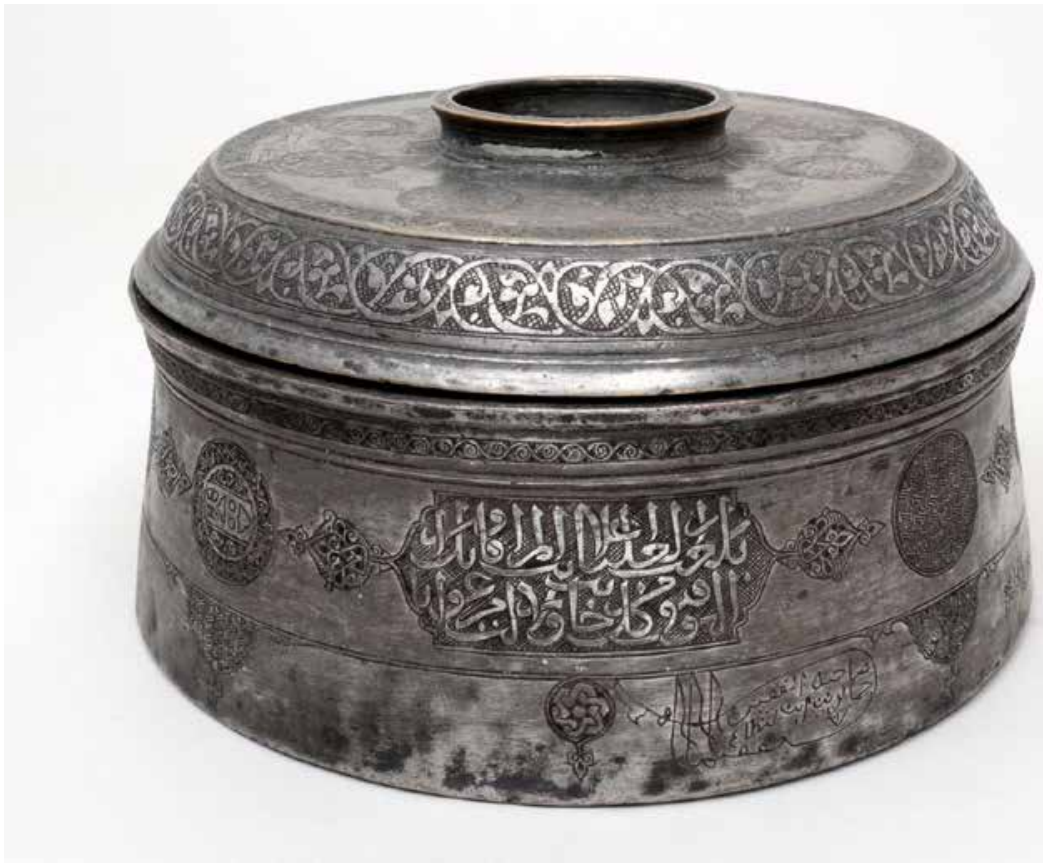

se často o typické ukázky výrobků z konkrétního regionu, podobně jako tomu bylo v daleko větší míre u rozsáhlejších světových uměleckoprůmyslových sbírek. Tuto koncepci odhaluje např́klad skromný soubor blízkovýchodní keramiky, který zahrnuje talíŕe z tureckého Izniku z 2. poloviny 16. století (inv. č. UMP 16494), vázu z Kütahye (inv. č. UMP 16683), dalšího významného střediska keramické výroby v Turecku, z konce 19. století, typické obkladačky opět z Izniku (inv. č. UMP 11812), ze syrských keramických dílen (inv. č. UMP 11811 a UMP 11816) nebo figurální kachle z 2. poloviny 19. století z Íránu (např. UMP 11819). Jsou to předměty, které byly $\mathrm{v}$ době akvizice již velmi populární, ale zároveň se jedná o ukázky předmětů $\mathrm{z}$ dílen, které měly silný vliv na umělecké řemeslo a zpracování dekoru v Evropě. Do této skupiny patří rovněž předměty, které mohou badatelưm stále poskytnout moment překvapení. Jsou to předměty, které byly nezaslouženě stranou zájmu správců sbírky, a přitom skrývají zajímavý př́běh a překvapivě zapadají do celého konceptu sbírky, ačkoliv to nejspíš nebylo původním záměrem při jejich pořízení. Takovým prŕíkladem může být keramická váza (inv. č. O/55)
Nádoba na potraviny. Egypt nebo Sýrie, konec 15. století. Měd', mosaz, pocínováno. Rozměry: v. $13 \mathrm{~cm}$ prüm. $25 \mathrm{~cm}$. Inv. č. UMP 4864. (Foto: Ivana Michnerová)

Náprstek Museum. Praha: Národní muzeum, 2012. ISBN 978-80-7036-334-8. 32 Nakajama - dnes součást města lčikawa $v$ prefektuře Čiba.

33 Faktura z 8. řijna 1908 $s$ podrobným popisem původu předmětú. (Kasovní doklady 1909, II, Umělecko průmyslové museum v Plzni, šanon 85, Archiv ZČM v Plzni.). $V$ popisu je sousoší označováno japonsky "Sanzonbutsu" a pan Saenger uvádí, že bylo umistěno původně $v$ chrámu $v$ provincii Jamato (dnešní prefektura Nara), později v soukromém vlastnictví a umístěno $v$ domácím oltárí. Saenger spojuje toto dílo se jménem umělce Unkei a obdobím Teidži (sic!). Japonský sochař Unkei (1148-1223) aktivní v období Kamakura (1185-1333), byl jedním z nejvýznamnějších japonských umělců, predstavitel nového realistického stylu. 


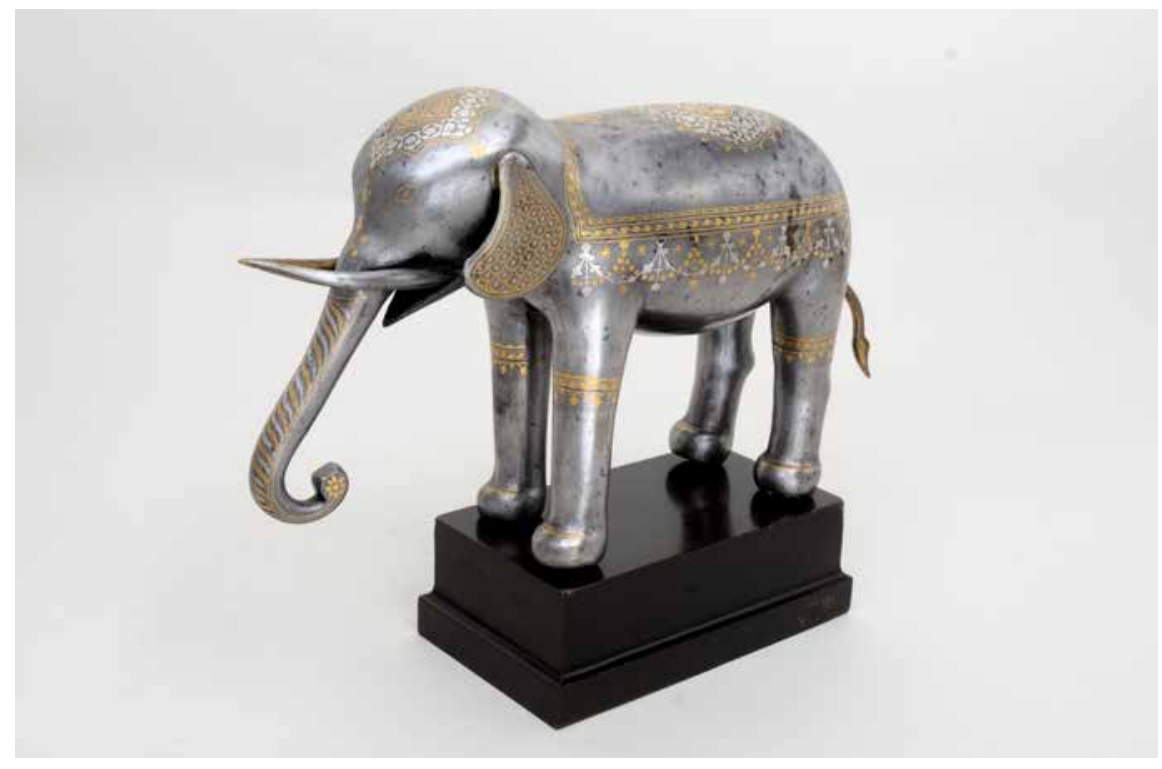

Plastika slona. Írán, 19. století. Ocel, výzdoba zlatem a stříbrem. Rozměry: v. $20 \mathrm{~cm}$, d. $33,5 \mathrm{~cm}$. Inv. č. UMP 4842. (Foto: Ivana Michnerová)

34 Autorem je buddhistický mnich Saemon, ve 4. roce éry Džókyó, v měsíci sacuki, št'astném dni kičiniči. BRAUNOVÁ,

Dagmar. Soupis exponátú do výstavy UMËNÍ ORIENTU. Plzeň 2004. Archiv autora. 35 Je možné, že víko bylo doplněno později. Dále viz MLEZIVA, J. Lunch box, Islamic metalwork from The West Bohemian Museum, Pilsen, In: Annals of the Náprstek Museum. Prague: The National Museum in Prague, No. 25, 2004, pp. 99-108.

36 Viz např. mosazná nádoba na potraviny složená ze tří mís a víka s rytou výzdobou a datovaná do 15.-16. století ve sbírce Britského muzea (inv. c. 1908,0328.2).

37 Konvice byla zakoupena v roce 1901 v Plzni od soukromého majitele.

38 SAHIN, Seracettin. The Museum of Turkish and Islamic Arts: thirteen centuries of glory from the Umayyads to the Ottomans. New York, NY: Blue

Dome Press, c2009, s. 299.

$39 K$ této problematice také viz MLEZIVA, Jindřich. Iznik or

Paris? Imitations of Ottoman pottery in the collection of the West Bohemian Museum in Pilsen. In: Annals of the Náprstek Museum. Prague: National Museum, 2016, No. $37 / 1$, pp. 33-40.

40 Mozaika vytvořená kombinací různobarevného dřeva, pocházející pravděpodobně z Íránu, která však byla v novějších poválečných popisech považována za čínskou porcelánovou vázu. Podle archivních záznamů však byla patrně získána Josefem Škorpilem v roce 1889 na světové výstavě v Pařiži jako "perská". Nádoba odhaluje problémy s nepřesnostmi v inventářích muzea, kam byly zaneseny v prủběhu 20. století. Nejedná se jen o tento konkrétní případ, ale i o další předměty, s jejichž určením se dnes kurátoři potýkají. ${ }^{39}$ Samotná nádoba kromě akviziční historie odhaluje i část historie vývoje keramiky v Asii. Váza skutečně měla za vzor čínský modrobílý porcelán, který byl z čínských císařských dílen exportován nejen do Evropy, ale i do zemí Blízkého východu. Stejně jako v Evropě i keramici na Blízkém východě se snažili napodobit jak materiál, tak i výzdobu. Podobně tomu bylo v osmanském Turecku (připomeňme rané iznické výrobky), ale také v safíjovském Íránu, kam řadíme plzeňskou nádobu. $\mathrm{V}$ tomto př́padě se nejedná o pečlivou napodobeninu čínské předlohy, ale spíše inspiraci čínským vzorem (to se týká tvaru, dekoru a dokonce i materiálu, který se měl blížit porcelánu). Podobné předměty se nevyráběly pouze pro místní trh, ale vyvážely se nějaký čas i do Evropy, patrně jako náhražka čínského modrobílého porcelánu v období výpadku produkce v Cíně $\mathrm{v}$ 17. století, který nastal $\mathrm{v}$ důsledku politických změn. Nádoba zřejmě zůstala v Íránu, jak napovídá kovová montáž s rytým dekorem, která pochází z pozdějšího období, tedy z 19. století. A teprve na konci 19. století se dostala do Evropy jako prodejní artikl.
Podobně i další předměty z jiných materiálů představují obvyklé zdobné techniky předmětů, jako je např. drobný nábytek zdobený technikou intarzie chátam-kárít ${ }^{40}$, vykládání dřevěných materiálù kostí a perletí. Nebo předměty $\mathrm{z}$ papírmašé. ${ }^{41}$ Malá skupina zbraní a zbroje ve sbírce představuje výzdobné techniky těchto předmětů. Soubor textilií včetně obuvi odhaluje problematiku řazení do určité uměleckohistorické skupiny. Většina předmětů byla zařazena do samostatného fondu evropského textilu. Kromě několika málo ukázek turecké výšivky je zde velká skupina textilií a fragmentů s výšivkami pocházející ze zemí Balkánského poloostrova, které kromě regionálních specifik reflektují také osmanskou výšivku 19. století v jejím městském i venkovském projevu. Podobná problematika s prolínáním kultur a geografických regionů se projevuje v případě skupiny šperků ze stejné geografické oblasti.

Sbírka asijského umění a uměleckého řemesla v Západočeském muzeu v Plzni, která dnes obsahuje téměř 1500 inventárních čísel, je stále předmětem studia a zdrojem

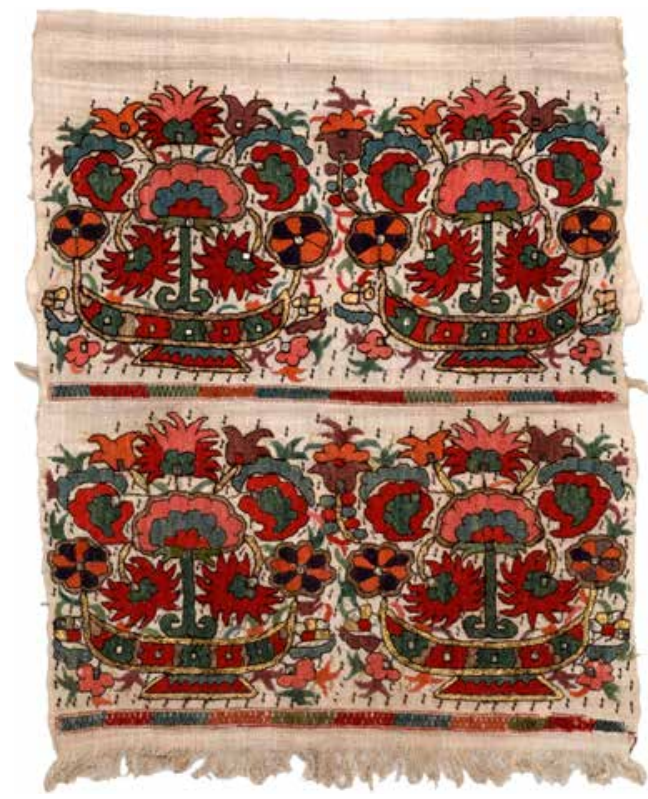

Ubrousek nebo ručník. Balkánský poloostrov, polovina 19. století. Bavlna, výšivka hedvábím a kovem. Rozměry: d. $138 \mathrm{~cm}$, s. $44 \mathrm{~cm}$. Inv. č. UMP 20133. (Foto: Ivana Michnerová) 
nových zajímavých objevů. V roce 2017 se po dlouhé době př́prav otevřela i uměleckoprůmyslová expozice, kde je široké veřejnosti prezentováno také umělecké řemeslo zemí Blízkého a Dálného východu.

\section{Fotografie}

Ivana Michnerová (ZČM v Plzni)

Václav Marian (ZČM v Plzni)

\section{Literatura}

BERNHARDT, Tomáš. Oferta na dodání nábytku pro novou budovu muzejní v Plzni. Plzeň: Západočeské muzeum v Plzni, 1999.

BRAUNOVÁ, Dagmar, FRÝDA, František, PISKÁČEK, Vladimír a MICHNEROVÁ, Ivana. Tibet: votivní a rituální umění. Plzeň: Západočeské muzeum v Plzni, 1999.

ČADÍK, Jindřich. Antické sklo: průvodce výstavou v Národním muzeu v Praze. Praha: Národní muzeum, 1970.

ČADÍK, Jindřich a ŠKORPIL, Václav. Bratři Škorpilové ve vzpomínkách. Pardubice: Východočeské muzeum, 1967.

Druhá zpráva Městského musea v Plzni za rok 1881. V Plzni: nákladem Musea, 1882.

FRÝDA, František. Josef Škorpil. Architekt a ředitel Uměleckoprůmyslového muzea v Plzni. In: Krásný život žili, krásnou práci konali --: nejslavnější generace rodu Škorpilů. Vysoké Mýto: Regionální muzeum, 2006, s. 41-49.

HÁNOVÁ, Markéta. Japonské dřevořezy a jejich sběratelé $v$ českých zemích. Praha: Národní galerie Praha, 2019.

HEJZLAROVÁ, Tereza. Umění a řmeslo Střední Asie. Textil a šperk. Praha: Univerzita Karlova, 2014.

HEJZLAROVÁ, Tereza, KLIMTOVÁ, Zdenka a POSPÍŠILOVÁ, Dagmar. Čechija respublikaci tŭplamlari $=$ The collections of the Czech Republic = Sobranija Češskoj Respubliki. Toškent: East Star Media, 2019.

HEROLDOVÁ, Helena a MLEZIVA, Jindřich. Činský textil ve sbírce Západočeského muzea v Plzni. Plzeň: Západočeské muzeum v Plzni, 2011.
HONCOOPOVÁ, Helena. The Puzzle of the Kishimojin altarpiece from Pilsen. In: Sborník Západočeského muzea v Plzni. Historie. Plzeň: Západočeské muzeum v Plzni, 2020. (v tisku)

KHALILI, Nasser. D. Lacquer of the Islamic Lands. London: The Nour Foundation, 1997.

KRAEMEROVÁ, Alice a GAUDEKOVÁ, Helena. Buddhové, bódhisattvové a božstva: buddhistické umění v japonské sbirce Náprstkova muzea = Buddhas, Bodhisattvas and Deities : Buddhist Art in the Japanese Collection of the Náprstek Museum. Praha: Národní muzeum, 2012.

MLEZIVA, Jindřich. Islámská figurální plastika. In: Nový Orient. Praha: Nový Orient, č. 3, roč. 60, 2005, s. 44-46.

MLEZIVA, Jindřich. Lunch box, Islamic metalwork from The West Bohemian Museum, Pilsen, In: Annals of the Náprstek Museum. Prague: The National Museum in Prague, 2004, No. 25, pp. 99-108.

MLEZIVA, Jindřich. Iranian Blue-AndWhite Ceramic Jar. In: Annals of the Náprstek Museum. Prague: National Museum, 2019, No. 40/1, pp. 121-132.

MLEZIVA, Jindřich. Iznik or Paris? Imitations of Ottoman pottery in the collection of the West Bohemian Museum in Pilsen. In: Annals of the Náprstek Museum. Prague: National Museum, 2016, No. 37/1, pp. 33-40.

MLEZIVA, Jindřich. Umělecké řemeslo Blizkého východu ve sbírce Západočeského muzea v Plzni. Plzeň: Západočeské muzeum, 2017.

Österreichisches Biographisches Lexikon und biographische Dokumentation [online]. Österreichischen Akademie der Wissenschaften, 2003-2018 [cit. 14. 10. 2010]. Dostupné z:

http://www.biographien.ac.at/oebl?frames $=$ yes

POSPÍŠILOVÁ, Dagmar a MLEZIVA, Jindřich. Umění kovu v zemích Blízkého východu a Indie. Praha: Národní muzeum, 2015.

ŘEHǑ̌, Vít. Historik Jindřich Čadik - životní osudy a dílo [online]. Plzeň, 2012 [cit. 2019-10-15]. Dostupné z: <https:// kosti a kovu (obvykle mosazi, zlata nebo střibra).

41 Tento materiál byl ve velké míře používán v 19. století v Íránu pod vládou Qádžárovců např. pro výrobu schránek na psací potřeby, které byly zdobeny po celé ploše pestrou malbou krytou lakem, často s figurálními náměty. Tato pouzdra se stala žádaným vývozním artiklem. $V$ muzejní sbírce je schránka s poměrně jednoduchou výzdobou s motivem růže a slavíka (gol o bolbol) (inv. č. UMP 18156). 
theses.cz/id/en0jdm/>. Diplomová práce. Západočeská univerzita v Plzni, Fakulta pedagogická.

ŞAHIN, Seracettin. The Museum of Turkish and Islamic Arts: thirteen centuries of glory from the Umayyads to the Ottomans. New York, NY: Blue Dome Press, c2009.

SLITINE, Florence. Samson, génie de l'imitation. Paris: Massin, 2002.

ŠKORPIL, Josef a PETÁK, Václav. Západočeské umělecko-průmyslové museum císaře a krále Frant. Josefa I. v Plzni: výroční zprávy z roku 1892-1908. Plzeň: nákladem Měst. uměl.-průmyslového musea, 1908.

SUCHOMEL, Filip. 3sta drahocenností: čínský porcelán ze sbirek Valdštejnu, Schwarzenbergů a Lichnowských. 2. přeprac. vyd. Praha: Vysoká škola uměleckoprůmyslová v Praze, 2015.
SUCHOMEL, Filip a ČERNÁ, Zlata. Puvaby orientálního salonu: umělecké řemeslo Dálného východu z jihomoravských a jihočeských zámeckých sbirek. V Brně: Národní památkový ústav, územní odborné pracoviště v Brně, 2007.

Západočeské umělecko-průmyslové museum císaře a krále Františka Josefa I. v Plzni: přehled ke dni otevření musea v neděli 13. července 1913. Plzeň: Západočeské umělecko-průmyslové museum, 1913.

\section{Prameny}

BRAUNOVÁ, Dagmar. Soupis exponátů do výstavy UMENIÍ ORIENTU. Plzeň, 2004. Nepublikovaný dokument. 